\title{
EDITORIAL
}

\section{The REMDACTA trial: do interleukin receptor antagonists provide additional benefit in COVID-19?}

\author{
Kate C. Tatham ${ }^{1,2}$, Manu Shankar-Hari ${ }^{3,4^{*}}$ (1) and Yaseen M. Arabi ${ }^{5}$
}

๑ 2021 Springer-Verlag GmbH Germany, part of Springer Nature

Coronavirus disease 2019 (COVID-19) is caused by severe acute respiratory syndrome coronavirus 2 (SARS$\mathrm{CoV}-2)$. Patients hospitalised with COVID-19 are at risk of clinical deterioration due to organ dysfunction [1], mostly commonly of the respiratory system, resulting in acute hypoxaemic respiratory failure. In COVID-19 patients, clinical deterioration due to worsening organ dysfunction increases the risk of adverse outcomes such as increased hospital length of stay and mortality. Worsening organ dysfunction is thought to occur secondary to either the harmful effects of the viral infection or the host immune responses or combinations thereof [2]. Thus, it is plausible that the addition of drugs targeting the host immune responses (such as interleukin-6 receptor antagonists like tocilizumab) to antiviral therapy could provide additional benefit over antiviral therapy alone in patients with COVID-19. This was the hypothesis tested in the REMDACTA trial by Rosas and colleagues [3].

The REMDACTA trial was a randomised double-blind placebo-controlled trial conducted in 53 centres in Brazil, Russia, Spain and the United States. The study population included hospitalised patients with proven SARS-CoV-2 infection, with radiological evidence of pneumonia and need for supplemental oxygen of at least $6 \mathrm{~L} / \mathrm{min}$. Nearly $88 \%$ of the trial population received corticosteroids during the 28-day follow-up period. This trial used 2:1 randomisation, with 434 patients randomly assigned to the tocilizumab plus remdesivir and 215 to the placebo plus remdesivir. Thus, the usual care was representative of the

*Correspondence: manu.shankar-hari@kcl.ac.uk

${ }^{3}$ Guy's and St Thomas' NHS Foundation Trust, St Thomas' Hospital, ICU Support Offices, 1st Floor, East Wing, London SE1 7EH, UK

Full author information is available at the end of the article current clinical practice guidelines [4], with the exception of remdesevir. Randomisation was stratified by geographic region and by clinical status at screening. Patients in the intervention arm received at least one dose of tocilizumab. The primary outcome was time from randomisation to either hospital discharge or ready for discharge to day-28, analysed as time to event, stratified by country and by baseline 7 -category clinical status ordinal scale. There was no difference in the primary outcome between the tocilizumab plus remdesivir and the placebo plus remdesivir groups (hazard ratio (HR) (95\% confidence interval (CI)) $0.97(0.78-1.19))$. The corresponding proportion of patients being $66.1 \%(n=286)$ in the tocilizumab plus remdesivir group and $67.1 \%(n=144)$ in the placebo plus remdesivir group. The 28 -day mortality was $18.1 \%$ in the tocilizumab plus remdesivir group and $19.5 \%$ in the placebo plus remdesivir group, with a HR (95\% CI) of 0.95 (0.65-1.39). The incidence of infections was similar in the tocilizumab plus remdesivir group $(30.5 \% ; n=131)$ and in the placebo plus remdesivir group $(33.3 \% ; n=71)$. The trial concluded that tocilizumab did not provide additional benefit, over and above usual care, that included remdesivir and corticosteroids.

Recently, a prospective meta-analysis (PMA) of interleukin- 6 antagonists, that included data from the REMDACTA trial, concluded that interleukin-6 receptor antagonists (tocilizumab and sarilumab) provide additional benefit compared to usual care (summary odds ratio (OR) for 28-day mortality, 0.86 (95\% CI, 0.79-0.95); $P=0.003$ based on a fixed-effects meta-analysis)[5]. Aside from the arguments that in the PMA the summary OR for 28-day mortality was 0.89 (95\% CI, 0.76-1.05; on a random-effect meta-analysis) and the differences in the tocilizumab treatment effects in the blinded versus open

\section{Springer}


label trials (summary OR $(95 \% \mathrm{CI}) 0.81(0.72,0.9)$ versus $0.95(0.72,1.26)[5])$, why are the conclusions of the REMDACTA trial on the additional benefit with tocilizumab different to the PMA? Of note, the OR $(95 \% \mathrm{CI})$ for 28-day mortality of REMDACTA trial within the PMA was $0.91(0.91(0.60-1.39))$ [5]. The fixed versus random effects debate is that in the fixed effect model we assume that there is one true effect size which is shared by all the included trials and in the random effects model we assume that the true effect could vary between the included trials. Accepting that the $95 \%$ CI will have driven how the studies are weighted and, therefore, sources of error, the similarities in the fixed and random effects point estimates observed in the PMA [5] makes a case to use interleukin- 6 receptor antagonists. The blinding versus open label effects debate is that blinding of the participants, healthcare providers and/or outcome assessors will prevent systematic differences in care provided or how the outcomes are assessed. When mortality is used as an outcome, as was the case in the PMA [5], the blinding versus open label debate is less relevant [6].

The trial population of REMDACTA trial appears similar to the RECOVERY Trial that showed benefit with tocilizumab, with one key difference: RECOVERY trial eligibility criteria included C-reactive protein (CRP) values $>75 \mathrm{mg} / \mathrm{L}$ as a marker of inflammation [7]. This generates the argument that CRP levels may be a useful biomarker to select or stratify patients. However, there was no heterogeneity of treatment effect within CRP categories (i.e. there was no difference in treatment effect with increasing C-reactive protein as a surrogate for greater inflammation) in the PMA [5]. The implications here are either that inflammation may not a good discriminant marker for tocilizumab treatment effect or that CRP is not an ideal biomarker for such stratification. For example, in rheumatoid arthritis where there is most experience with these medications, drug levels and patients with low serum levels of intracellular adhesion molecule-1 (ICAM1) levels and high chemokine ligand 13 (CXCL13) levels showed the greatest response to tocilizumab [8]. Thus, the much pushed argument to measure IL-6 levels as a predictive biomarker for tocilizumab may well be ill founded. Of note, IL-6 levels in COVID-19 are lower than other critical illnesses such as sepsis [9].

Higher viral loads within the respiratory tract are seen in deteriorating and in critically ill COVID-19 patients $[10,11]$. Presence of virus in the respiratory tract activates the immune system, particularly $\mathrm{T}$ cells. Activated $\mathrm{T}$ cells produce chemokines which attract monocytes and transform them into inflammatory macrophages within the lungs. Inflammatory macrophages generate chemokines that attract more $\mathrm{T}$ cells into the already inflamed lung parenchyma. This lymphocyte-macrophage inflammatory circuit continues until viral clearance and causes lung damage [12]. Circulating SARS-CoV-2 RNA is detected in blood in 20\% of critically ill patients [13]. Both respiratory viral load and presence of viral RNA in blood is associated with increased risk of severe disease and adverse outcomes such as death [11]. Therefore, a combination of antiviral drug with an IL-6RA could accelerate viral clearance, whilst providing immunomodulation. In the REMDACTA trial, although eligibility criteria included a positive SARS-CoV-2 polymerase chain reaction test within 7 days of randomisation, viral load information is unavailable to explore the above hypothesis. However, the use of remdesivir as usual care [14] perhaps makes this line of reasoning less important. A related argument to consider here is that in patients who receive remdesivir and corticosteroids as cointerventions, there is limited additional benefit with tocilizumab. However, in the RECOVERY Trial that enrolled a similar target population, there was additional benefit with tocilizumab in those patients who got corticosteroids [7], a treatment effect that was replicated in critically ill patients [15] and in all illness severity states within the PMA [5].

The authors modified the primary outcome during the trial. At the start of the trial, the primary outcome was clinical status assessed on an ordinal scale at day- 28 to time from randomisation, which was modified to either hospital discharge or ready for discharge to day-28. The ready for discharge is a more sensitive, and subjective outcome. As a double-blind trial, outcome ascertainment is unlikely to be biased, despite being subjective. However, a more sensitive outcome would be expected to increase the event rate, which leads us to discuss the sample size calculations in the trial. The authors were expecting 520 events and a 2.5 day shorter time to hospital discharge or ready for discharge to day-28, to achieve a treatment effect using Hazard Ratio of 1.3. Aside from expecting an optimistic treatment effect, they observed lesser primary outcome events $(n=430)$ than expected. In a fixed sample size frequentist design, this reduces the likelihood of a confirmatory result. Thus, whether the trial results would have been different with more outcome events is a valid critique.

In summary, REMDACTA trial did not show additional benefit with tocilizumab. The treatment effects observed in the trial was within the confidence interval reported in the PMA, that informed the World Health Organisation living guidelines to recommend interleukin-6 receptor antagonists in the management of COVID-19 patients.

\footnotetext{
Author details

${ }^{1}$ Royal Marsden NHS Foundation Trust, 203 Fulham Road, London SW3 6J, UK. ${ }^{2}$ Department of Surgery and Cancer, Imperial College London, London,
} 
England, UK. ${ }^{3}$ Guy's and St Thomas' NHS Foundation Trust, St Thomas' Hospital, ICU Support Offices, 1st Floor, East Wing, London SE1 7EH, UK. ${ }^{4}$ School of Immunology and Microbial Sciences, Kings College London, 5th Floor, Southwark Wing, London SE1 9RT, UK. ${ }^{5}$ King Abdullah International Medical Research Centre, Ministry of National Guard Health Affairs, King Saud Bin Abdulaziz University for Health Sciences, Riyadh, Kingdom of Saudi Arabia.

\section{Author contributions}

All authors developed the outline. MSH wrote the first draft. All authors contributed to the critical revision of the manuscript for important intellectual content.

\section{Funding}

MS-H is supported by the National Institute for Health Research Clinician Scientist Award (CS-2016-16-011). The views expressed in this publication are those of the author(s) and not necessarily those of the NHS, the National Institute for Health Research or the Department of Health and social care.

\section{Declarations}

\section{Conflicts of interest}

KCT declares no competing interests. MS-H is on the Editorial Board for ICM, an investigator on the REMAP-CAP trial, led the WHO REACT PMA on IL-6 antagonists. YA is on the Editorial Board for ICM and is an investigator on the REMAP-CAP trial.

\section{Publisher's Note}

Springer Nature remains neutral with regard to jurisdictional claims in published maps and institutional affiliations.

Received: 16 September 2021 Accepted: 17 September 2021 Published online: 7 October 2021

\section{References}

1. Marshall JC, Murthy S, Diaz J, Adhikari NK, Angus DC, Arabi YM, Baillie K, Bauer M, Berry S, Blackwood B, Bonten M, Bozza F, Brunkhorst F, Cheng A, Clarke M, Dat VQ, de Jong M, Denholm J, Derde L, Dunning J, Feng X, Fletcher T, Foster N, Fowler R, Gobat N, Gomersall C, Gordon A, Glueck T, Harhay M, Hodgson C, Horby P, Kim Y, Kojan R, Kumar B, Laffey J, Malvey D, Martin-Loeches I, McArthur C, McAuley D, McBride S, McGuinness S, Merson L, Morpeth S, Needham D, Netea M, Oh M-D, Phyu S, Piva S, Qiu R, Salisu-Kabara H, Shi L, Shimizu N, Sinclair J, Tong S, Turgeon A, Uyeki T, van de Veerdonk F, Webb S, Williamson P, Wolf T, Zhang J (2020) A minimal common outcome measure set for COVID-19 clinical research. Lancet Infect Dis 20:e192-e197

2. Osuchowski MF, Winkler MS, Skirecki T, Cajander S, Shankar-Hari M, Lachmann G, Monneret G, Venet F, Bauer M, Brunkhorst FM, Weis S, Garcia-Salido A, Kox M, Cavaillon JM, Uhle F, Weigand MA, Flohe SB, Wiersinga WJ, Almansa R, de la Fuente A, Martin-Loeches I, Meisel C, Spinetti T, Schefold JC, Cilloniz C, Torres A, Giamarellos-Bourboulis EJ, Ferrer R, Girardis M, Cossarizza A, Netea MG, van der Poll T, Bermejo-Martin JF, Rubio I (2021) The COVID-19 puzzle: deciphering pathophysiology and phenotypes of a new disease entity. Lancet Respir Med 9:622-642

3. Rosas IO, Diaz G, Gottlieb RL, Lobo SM, Robinson P, Hunter BD, Cavalcante AW, Overcash JS, Hanania NA, Skarbnik A, Garcia-Diaz J, Gordeev I, Carratal J, Gordon O, Graham E, Lewin-Koh N, Tsai L, Tuckwell K, Cao H, Brainard D, Olsson JK (2021) Tocilizumab and remdesivir in hospitalized patients with severe COVID-19 pneumonia: a randomized clinical trial. Intensive Care Med. https://doi.org/10.1007/s00134-021-06507-x

4. Rochwerg B, Agarwal A, Siemieniuk RA, Agoritsas T, Lamontagne F, Askie L, Lytvyn L, Leo YS, Macdonald H, Zeng L, Amin W, Burhan E, Bausch FJ, Calfee CS, Cecconi M, Chanda D, Du B, Geduld H, Gee P, Harley N, Hashimi M, Hunt B, Kabra SK, Kanda S, Kawano-Dourado L, Kim YJ, Kissoon N, Kwizera A, Mahaka I, Manai H, Mino G, Nsutebu E, Preller J, Pshenichnaya N, Qadir N, Sabzwari S, Sarin R, Shankar-Hari M, Sharland M, Shen Y, Ranganathan SS, Souza JP, Stegemann M, De Sutter A, Ugarte S, Venkatapuram S, Dat VQ, Vuyiseka D, Wijewickrama A, Maguire B, Zeraatkar D, Bartoszko
JJ, Ge L, Brignardello-Petersen R, Owen A, Guyatt G, Diaz J, Jacobs M, Vandvik PO (2020) A living WHO guideline on drugs for covid-19. BMJ 370:m3379

5. Group WHOREAfC-TW, Shankar-Hari M, Vale CL, Godolphin PJ, Fisher D, Higgins JPT, Spiga F, Savovic J, Tierney J, Baron G, Benbenishty JS, Berry LR, Broman N, Cavalcanti AB, Colman R, De Buyser SL, Derde LPG, Domingo P, Omar SF, Fernandez-Cruz A, Feuth T, Garcia F, Garcia-Vicuna R, GonzalezAlvaro I, Gordon AC, Haynes R, Hermine O, Horby PW, Horick NK, Kumar K, Lambrecht BN, Landray MJ, Leal L, Lederer DJ, Lorenzi E, Mariette X, Merchante N, Misnan NA, Mohan SV, Nivens MC, Oksi J, Perez-Molina JA, Pizov R, Porcher R, Postma S, Rajasuriar R, Ramanan AV, Ravaud P, Reid PD, Rutgers A, Sancho-Lopez A, Seto TB, Sivapalasingam S, Soin AS, Staplin N, Stone JH, Strohbehn GW, Sunden-Cullberg J, Torre-Cisneros J, Tsai LW, van Hoogstraten H, van Meerten T, Veiga VC, Westerweel PE, Murthy S, Diaz JV, Marshall JC, Sterne JAC (2021) Association between administration of IL-6 Antagonists and mortality among patients hospitalized for COVID-19: a meta-analysis. JAMA 326:499-518

6. Anthon CT, Granholm A, Perner A, Laake JH, Moller MH (2018) No firm evidence that lack of blinding affects estimates of mortality in randomised clinical trials of intensive care interventions: a systematic review and meta-analysis. J Clin Epidemiol 100:71-81

7. Abani O, Abbas A, Abbas F, Abbas M, Abbasi S, Abbass H et al (2021) Tocilizumab in patients admitted to hospital with COVID-19 (RECOVERY): a randomised, controlled, open-label, platform trial. Lancet 397:1637-1645

8. Nouri B, Nair N, Barton A (2020) Predicting treatment response to IL6R blockers in rheumatoid arthritis. Rheumatology (Oxford) 59:3603-3610

9. Leisman DE, Ronner L, Pinotti R, Taylor MD, Sinha P, Calfee CS, Hirayama AV, Mastroiani F, Turtle CJ, Harhay MO, Legrand M, Deutschman CS (2020) Cytokine elevation in severe and critical COVID-19: a rapid systematic review, meta-analysis, and comparison with other inflammatory syndromes. Lancet Respir Med 8:1233-1244

10. Ratcliff J, Nguyen D, Fish M, Rynne J, Jennings A, Williams S, Al-Beidh F, Bonsall D, Evans A, Golubchik T, Gordon AC, Lamikanra A, Tsang P, Ciccone NA, Leuscher U, Slack W, Laing E, Mouncey PR, Ziyenge S, Oliveira M, Ploeg R, Rowan KM, Shankar-Hari M, Roberts DJ, Menon DK, Estcourt L, Simmonds P, Harvala H (2021) Virological and serological characterization of critically ill patients with COVID-19 in the UK: interactions of viral load, antibody status and B.1.1.7 variant infection. J Infect Dis 224:595-605

11. Boyapati A, Wipperman MF, Ehmann PJ, Hamon S, Lederer DJ, Waldron A, Flanagan JJ, Karayusuf E, Bhore R, Nivens MC, Hamilton JD, Sumner G, Sivapalasingam S (2021) Baseline SARS-CoV-2 viral load is associated with COVID-19 disease severity and clinical outcomes: post-hoc analyses of a phase 2/3 trial. J Infect Dis. https://doi.org/10.1093/infdis/jiab445

12. Grant RA, Morales-Nebreda L, Markov NS, Swaminathan S, Querrey M, Guzman ER, Abbott DA, Donnelly HK, Donayre A, Goldberg IA, Klug ZM, Borkowski N, Lu Z, Kihshen H, Politanska Y, Sichizya L, Kang M, Shilatifard A, Qi C, Lomasney JW, Argento AC, Kruser JM, Malsin ES, Pickens CO, Smith SB, Walter JM, Pawlowski AE, Schneider D, Nannapaneni P, AbdalaValencia H, Bharat A, Gottardi CJ, Budinger GRS, Misharin AV, Singer BD, Wunderink RG, Investigators NSS (2021) Circuits between infected macrophages and T cells in SARS-CoV-2 pneumonia. Nature 590:635-641

13. Gutmann C, Takov K, Burnap SA, Singh B, Ali H, Theofilatos K, Reed E, Hasman M, Nabeebaccus A, Fish M, McPhail MJ, O'Gallagher K, Schmidt LE, Cassel C, Rienks M, Yin X, Auzinger G, Napoli S, Mujib SF, Trovato F, Sanderson B, Merrick B, Niazi U, Saqi M, Dimitrakopoulou K, Fernandez-Leiro R, Braun S, Kronstein-Wiedemann R, Doores KJ, Edgeworth JD, Shah AM, Bornstein SR, Tonn T, Hayday AC, Giacca M, Shankar-Hari M, Mayr M (2021) SARS-CoV-2 RNAemia and proteomic trajectories inform prognostication in COVID-19 patients admitted to intensive care. Nat Commun 12:3406

14. Beigel JH, Tomashek KM, Dodd LE, Mehta AK, Zingman BS, Kalil AC, Hohmann E, Chu HY, Luetkemeyer A, Kline S, Lopez de Castilla D, Finberg RW, Dierberg K, Tapson V, Hsieh L, Patterson TF, Paredes R, Sweeney DA, Short WR, Touloumi G, Lye DC, Ohmagari N, Oh MD, Ruiz-Palacios GM, Benfield T, Fatkenheuer G, Kortepeter MG, Atmar RL, Creech CB, Lundgren J, Babiker AG, Pett S, Neaton JD, Burgess TH, Bonnett T, Green M, Makowski M, Osinusi A, Nayak S, Lane HC, Members A-SG (2020) Remdesivir for the treatment of Covid-19-final report. N Engl J Med 383:1813-1826

15. Investigators R-C, Gordon AC, Mouncey PR, Al-Beidh F, Rowan KM, Nichol AD, Arabi YM, Annane D, Beane A, van Bentum-Puijk W, Berry LR, Bhimani Z, Bonten MJM, Bradbury CA, Brunkhorst FM, Buzgau A, Cheng AC, Detry 
MA, Duffy EJ, Estcourt LJ, Fitzgerald M, Goossens H, Haniffa R, Higgins AM, Hills TE, Horvat CM, Lamontagne F, Lawler PR, Leavis HL, Linstrum KM, Litton E, Lorenzi E, Marshall JC, Mayr FB, McAuley DF, McGlothlin A, McGuinness SP, McVerry BJ, Montgomery SK, Morpeth SC, Murthy S, Orr K, Parke RL, Parker JC, Patanwala AE, Pettila V, Rademaker E, Santos MS, Saunders
CT, Seymour CW, Shankar-Hari M, SligI WI, Turgeon AF, Turner AM, van de Veerdonk FL, Zarychanski R, Green C, Lewis RJ, Angus DC, McArthur CJ, Berry S, Webb SA, Derde LPG (2021) Interleukin-6 receptor antagonists in critically ill patients with Covid-19. N Engl J Med 384:1491-1502 